\title{
Erythrocyte sodium-lithium countertransport and blood pressure in identical twin pairs discordant for insulin dependent diabetes
}

\author{
Timothy C Hardman, Simon W Dubrey, David G Leslie, Mohamed Hafiz, Mark I Noble, \\ Ariel F Lant
}

\begin{abstract}
Department of Clinical Pharmacology and Therapeutics, Charing Cross and Westminster Medical School Westminster Hospital, London SW1P 2AP Timothy C Hardman, research fellow

David G Leslie, Wellcome senior research fellow Mohamed Hafiz, research assistant

Ariel F Lant, professor of clinical pharmacology and therapeutics
\end{abstract}

\section{Academic Unit of} Cardiovascular Medicine, Charing Cross and Westminster Medical School, Westminster Hospital, London SW1P 2AP

Simon W Dubrey, clinical research fellow

Mark I Noble, professor of cardiovascular medicine

Correspondence to: Professor Lant.

BM7 1992;305:215-9

\begin{abstract}
Objective-To investigate whether insulin dependent diabetes is responsible for the abnormal behaviour of the carrier in sodium-lithium countertransport and whether the diabetic state is associated with rise in blood pressure.

Design-Case-control study.

Setting-London teaching hospital.

Subjects -44 twin pairs discordant for insulin dependent diabetes living in United Kingdom and 44 healthy control subjects matched for age, sex, and body mass index. None of the twin pairs or the controls had evidence of microalbuminuria.

Main outcome measures-Sodium-lithium countertransport activity in erythrocytes and arterial blood pressure.

Results-The mean (95\% confidence interval) sodium-lithium countertransport activity $(\mathrm{mmol} \mathrm{Li}$ per litre of red blood cells per $h$ ) of the diabetic twins $(0.291(0.244$ to 0.338$))$ was similar to that of their non-diabetic cotwins $(0.247(0.204$ to 0.290$))$; both values were significantly higher than that of the controls $(0.187 \quad(0.157$ to 0.216$) ; p<0.05)$. In addition, systolic blood pressure was higher in those twins with diabetes $(127(122$ to 133$) \mathrm{mm} \mathrm{Hg}$ ) than in the non-diabetic cotwins (122 (117 to 127$) \mathrm{mm} \mathrm{Hg}$; $\mathrm{p}<0.01)$. There were no significant differences in mean diastolic blood pressure between any of the groups studied.

Conclusions-The raised erythrocyte sodiumlithium countertransport activity in the diabetic twins compared with the controls seems to be inherited rather than a consequence of overt diabetes. The higher systolic blood pressure in diabetic twins than non-diabetic cotwins indicates that insulin dependent diabetes does exert a small influence on systolic blood pressure.
\end{abstract}

\section{Introduction}

Sodium-lithium countertransport in erythrocytes is increased in patients with essential hypertension and has been proposed as a genetic marker for this condition. ' Increased sodium-lithium countertransport has also been found in patients with insulin dependent diabetes mellitus, both with ${ }^{34}$ and without " coexisting nephropathy, implying that the diabetic state itself may be another determinant of countertransport activity.

Familial factors seem important because first degree relatives of patients with essential hypertension, who show no sign of the disease, may also exhibit increased sodium-lithium countertransport.' Familial factors possibly related to the development of hypertension may also feature in the susceptibility to diabetic nephropathy."

To explore whether insulin dependent diabetes is responsible for the abnormal behaviour of the carrier involved in erythrocyte sodium-lithium countertransport and whether the diabetic state in itself is associated with increases in blood pressure we studied a group of identical twins discordant for diabetes. Diabetic twins were compared with their non-diabetic cotwins and a control non-diabetic subject individually matched with twin pairs for age, sex, and body mass index. None of the twins or controls was hypertensive, receiving antihypertensive drugs, or had any clinical evidence of nephropathy.

\section{Patients and methods}

The British diabetic identical twin study includes 321 identical twin pairs with 208 pairs having an index twin with insulin dependent diabetes." Forty four twin pairs from this group were eligible for study by fulfilling the following criteria: discordance for diabetes, aged between 20 and 65 years, Caucasian origin, both twins available for study, absence of hypertension and not taking prescribed antihypertensive drugs, no evidence of microalbuminuria. All the diabetic twins had been treated from time of diagnosis with insulin and each currently was controlled with either highly purified porcine or human insulin. The mean (SD) age at diagnosis of diabetes in the index twin was $20 \cdot 8$ (11.9) years and the mean (SD) duration of diabetes was $16 \cdot 6(7 \cdot 1)$ years.

We studied 285 healthy control subjects ( 175 men, 110 women, age range 20-65 years) at the same time as the twins; they were employees of two large London based firms (a clothes retailer and an insurance broker) and were not part of the hospital community (staff or patients), had no family history of diabetes, and were not taking any drugs at the time of investigation. Forty four control subjects, who were drawn from this local urban population, were individually matched with twin pairs to within $5 \%$ with respect to age and body mass index; they also had the same distribution with respect to sex.

All the subjects were examined in hospital between 10 am and $4 \mathrm{pm}$. Subjects gave informed consent and the study was approved by Westminster Hospital ethics committee. A full medical history was obtained from each subject. Information was requested regarding any family history of diabetes, hyperlipidaemia, renal disease, or hypertension. Height and weight were measured with the subjects in light clothing without shoes. Blood pressure was taken as the mean of three measurements of systolic and diastolic pressure taken from the right arm after the subject had been sitting for at least 10 minutes in a quiet setting. Readings were based on Korotkoff sounds I and V and taken five minutes apart by the same observer (SWD), to the nearest $2 \mathrm{~mm} \mathrm{Hg}$, with a standard mercury sphygmomanometer and the appropriately sized arm cuff. 
Hypertension was defined according to the World Health Organisation criteria (blood pressure exceeding $160 / 95 \mathrm{~mm} \mathrm{Hg}$ ). ${ }^{16}$ Diabetes was excluded in all the nondiabetic cotwins by a $75 \mathrm{~g}$ oral glucose tolerance test and by a random whole blood glucose analysis at the time of the test. Normal blood glucose concentrations were defined as a whole blood glucose concentration less than $5.6 \mathrm{mmol} / \mathrm{l}$ when fasting and less than 6.7 $\mathrm{mmol} / \mathrm{l}$ two hours after the oral glucose load."

Blood samples were taken by venepuncture for biochemical analysis, confirmation of monozygosity, and determination of sodium-lithium countertransport activity. Timed urine samples were also collected from $10 \mathrm{pm}$ to 8 am during the night before the study.

\section{BIOCHEMICAL ANALYSES}

Monozygosity between the twins was established by at least 12 tests of blood group as previously described. ${ }^{9}$ Whole blood glucose concentration was measured by the glucose oxidase method (Yellow Springs Instruments, Yellow Springs, Ohio). Glycated haemoglobin concentration was measured by electroendosmosis with the Corning method (Corning Chemical, Palo Alto, California), with a normal range for the laboratory of $5 \cdot 0-8 \cdot 0 \%$. Serum and urinary creatinine concentrations were measured on an automatic analyser (BM/Hitachi 717, Boehringer Mannheim, Lewes, United Kingdom).

The urinary albumin excretion rate was assessed on a fresh, timed overnight urine sample on the day of attendance for the study. Urinary albumin concentration was measured by rate nephelometry (Beckman Array, Beckman, High Wycombe, United Kingdom) with the standard Beckman microalbumin reagent. The method has a minimum detection limit of $2 \mathrm{mg} / \mathrm{l}$. The urinary albumin excretion rates were factored for simultaneous urinary creatinine concentration. Values were regarded as being significantly raised if the urinary albumin to creatinine ratio was greater than 1.4 $\mathrm{mg}$ of albumin per mmol of creatinine. ${ }^{12}$

\section{DETERMINATION OF SODIUM-LITHIUM}

COUNTERTRANSPORT ACTIVITY

All sodium-lithium countertransport measurements were undertaken blind to the subjects' clinical state. Sodium-lithium countertransport activity was determined by a method based on that published by Canessa et al. ${ }^{7}$ Blood was drawn into heparin treated vacutainers, the haemoglobin content of the erythrocytes measured by the cyanomethaemoglobin method,,$^{13}$ and the mean cellular haemoglobin content of the erythrocytes determined. Within three hours of sampling erythrocytes were separated by centrifugation from the plasma and buffy coat and then resuspended in a preserving solution $(140 \mathrm{mM}$ potassium chloride; $10 \mathrm{mM}$ sodium chloride; $1 \mathrm{mM}$ magnesium chloride; $5 \mathrm{mM}$ glucose; $10 \mathrm{mM}$ TRIS-morpholinopropane sulphonic acid buffer, $\mathrm{pH} 7.4$ at $4^{\circ} \mathrm{C}$ ). The cells were stored at $4^{\circ} \mathrm{C}$ until analysis. Countertransport activity was determined on the day of blood collection or after overnight preservation of samples at $4^{\circ} \mathrm{C}$.

Erythrocytes were washed three times with an iso-osmotic magnesium solution $(75 \mathrm{mM}$ magnesium chloride; $85 \mathrm{mM}$ sucrose; $10 \mathrm{mM}$ TRIS-morpholinopropane sulphonic acid buffer, $\mathrm{pH} 7 \cdot 4$ at $4^{\circ} \mathrm{C}$ ). After the final wash the supernatant was aspirated and discarded. A total of $5 \mathrm{ml}$ of packed erythrocytes was suspended in $25 \mathrm{ml}$ of loading solution $(150 \mathrm{mM}$ lithium chloride; $10 \mathrm{mM}$ glucose; $10 \mathrm{mM}$ TRISmorpholinopropane sulphonic acid buffer, $\mathrm{pH} 7 \cdot 4$ at $37^{\circ} \mathrm{C}$ ) and incubated at $37^{\circ} \mathrm{C}$ for three hours. At the end of the incubation the erythrocytes were washed five times with washing solution $(75 \mathrm{mM}$ magnesium chloride; $85 \mathrm{mM}$ sucrose; $0.1 \mathrm{mM}$ ouabain; $10 \mathrm{mM}$ TRIS-morpholinopropane sulphonic acid buffer, $\mathrm{pH}$
$7 \cdot 4$ at $4^{\circ} \mathrm{C}$ ). After the final wash the supernatant was discarded and the packed cell volume of the suspension of erythrocytes determined. The mean cellular haemoglobin content was measured once more to ensure that the loading procedure had not resulted in a change in cell volume. The intracellular sodium and lithium concentrations were also analysed to ensure that internal lithium concentrations were sufficient to saturate the countertransporter.

Packed erythrocytes $(1.6 \mathrm{ml})$ were suspended in either sodium rich $(150 \mathrm{mM}$ sodium chloride; $10 \mathrm{mM}$ glucose; $0 \cdot 1 \mathrm{mM}$ ouabain; $10 \mathrm{mM}$ TRIS-morpholinopropane sulphonic acid buffer, $\mathrm{pH} 7.4$ at $37^{\circ} \mathrm{C}$ ) oro sodium free (75 mM magnesium chloride; $85 \mathrm{mM}$ 흐 sucrose; $10 \mathrm{mM}$ glucose; $0.1 \mathrm{mM}$ ouabain; $10 \mathrm{mM}$ के TRIS-morpholinopropane sulphonic acid buffer, $\mathrm{pH} \underset{\Omega}{\widetilde{Q}}$ $7 \cdot 4$ at $37^{\circ} \mathrm{C}$ ) media. Aliquots were taken in duplicate at 20,40 , and 60 minutes; placed on ice for one minute; ${ }^{\infty}$ and then separated by centrifugation for one minute in. a microcentrifuge to estimate lithium efflux. The $\vec{\overrightarrow{ }}$ lithium concentrations in the supernatants of these $\omega$ aliquots were determined by atomic absorption spectrophotometry (Model 603, Perkin Elmer, Buckinghamshire). Sodium-lithium countertransport was determined by subtracting the lithium efflux into the sodium free medium from that which occurred into the sodium rich medium expressed as millimoles of - lithium released from one litre of erythrocytes per hour. ${ }^{14}$

The mean (SD) of the control values for sodium- $\frac{\text { ? }}{2}$ lithium countertransport activity in this study was $N$ determined from the values for the total population of $C$ healthy control subjects investigated and was $0 \cdot 196<$ $(0 \cdot 107) \mathrm{mmol} \mathrm{Li} / \mathrm{l}$ of red blood cells/h $(\mathrm{n}=285)$. To $\vec{\bullet}$ ensure that maintaining cells in preservation solution $\mathrm{e}$ for 24 hours did not influence sodium-lithium countertransport activity, countertransport was measured in five additional men, immediately after collection of blood and after storing the sample overnight in preserving solution at $4^{\circ} \mathrm{C}$. The mean (SD) difference $\frac{0}{\mathrm{O}}$ $(\mathrm{mmol} \mathrm{Li} / \mathrm{l}$ of red blood cells/h) of $0.018(0.005) \varrho$ between the mean sodium-lithium countertransport $\overrightarrow{0}$ activities of the fresh $(0.203(0.071))$ and preserved 3 $(0 \cdot 202(0 \cdot 079))$ cells was not significant. Sodiumlithium countertransport activity was also measured in triplicate on fresh cells from 10 further subjects on two to seven occasions over the 16 months of this study. The mean interassay and the intraindividual coefficients of variation were calculated from these results and found to be $6.5 \%$ and $10 \cdot 8 \%$ respectively. These levels for technical error and intraindividual variation are similar to those reported by others. ${ }^{15}{ }^{16}$ The analyseso indicated that a single measurement provided a reliable estimate of a person's sodium-lithium countertransport activity. ${ }^{17}$

\section{STATISTICAL METHODS}

Results are expressed as means (SDs) or means with $95 \%$ confidence intervals. Data were initially analysed by paired Student's $t$ tests; $\mathrm{p}$ values less than 0.05 wereo considered significant. Differences between twin $\bar{D}$ groups and the controls were further confirmed by? analysis of variance in conjunction with a NewmanKeuls test. Associations within twin pairs for blood $\stackrel{\mathrm{D}}{\mathrm{D}}$ pressure and for countertransport were assessed by product moment correlation.

\section{Results}

The 44 twin pairs studied were normotensive, were not receiving any antihypertensive drugs, and showedЭ no appreciable proteinuria or microalbuminuria (albumin excretion $<1.4 \mathrm{mg} / \mathrm{mmol}$ of creatinine, table I). The mean (SD) duration of diabetes in the diabetic twins was $16 \cdot 6(7 \cdot 1)$ years. There was no difference 
between the diabetic and the non-diabetic cotwins $(\mathrm{p}=$ $0.83)$, the diabetic twins and controls $(p=0.35)$, or the controls and the non-diabetic cotwins $(p=0.52)$ with respect to serum creatinine concentration (table I). The mean $(\mathrm{SD})$ random blood glucose concentration in the diabetic twins $(9 \cdot 9(5 \cdot 4) \mathrm{mmol} / \mathrm{l})$ was greater than that of the non-diabetic cotwins $(5.3(0.9) \mathrm{mmol} / \mathrm{l}$ $\mathrm{p}<0.001)$ and controls $(5 \cdot 1(0.6) \mathrm{mmol} / \mathrm{l} ; \mathrm{p}<0.001)$. In addition, the glycated haemoglobin concentration in the diabetic twins $(9 \cdot 7(1.9) \%)$ was higher than in both the non-diabetic cotwins $(7 \cdot 1(1 \cdot 9) \% ; \mathrm{p}<0.001)$ and the controls $(6.4(0.8) \% ; \mathrm{p}<0.001)$. The concentrations of blood glucose and glycated haemoglobin in the non-diabetic twins and the control subjects did not differ significantly $(\mathrm{p}=0 \cdot 20$ and $\mathrm{p}=0 \cdot 14$ respectively $)$.

TABLE I-Clinical and laboratory data for 44 insulin dependent diabetic twins, their non-diabetic cotwins, and 44 matched control subjects. Results are expressed as means (SD)

\begin{tabular}{|c|c|c|c|}
\hline & $\begin{array}{l}\text { Diabetic } \\
\text { twins }\end{array}$ & $\begin{array}{l}\text { Non-diabetic } \\
\text { cotwins }\end{array}$ & Controls \\
\hline $\operatorname{Sex}(M / F)$ & & $23 / 21$ & $23 / 21$ \\
\hline & $37 \cdot$ & & \\
\hline index $\mathrm{kg} / \mathrm{m}$ & $24 \cdot 5(2 \cdot 8)$ & $24 \cdot 6(3$ & $23 \cdot 8(2 \cdot 6)$ \\
\hline & 8.6 .11 & $87 \cdot 6(1$ & $90 \cdot 9(12 \cdot 2)$ \\
\hline Blood glucose $(\mathrm{mmol} / \mathrm{l})$ & $9 \cdot 9(5 \cdot 4$ & $5 \cdot 3(0 \cdot 9)$ & $5 \cdot 1(0 \cdot 6)$ \\
\hline Glycated haemoglobin $(\%)$ & $9 \cdot 7(1.9)^{\star}$ & $7 \cdot 1(1.9)$ & $6 \cdot 4(0 \cdot 8)$ \\
\hline $\begin{array}{l}\text { Urinary albumin excretion rate } \\
(\mathrm{mg} / \mathrm{mmol} \text { creatinine })\end{array}$ & $0.750(0.508)$ & $0.539(0.203)$ & $0.498(0 \cdot 223$ \\
\hline
\end{tabular}

${ }^{\star} \mathrm{p}<0.001$ Compared with value in the non-diabetic cotwins

Sodium-lithium countertransport activity $(\mathrm{mmol}$ $\mathrm{Li} / \mathrm{l}$ of red blood cells/h) was higher in both the diabetic twins $(0.291(0 \cdot 160) ; \mathrm{p}<0.001)$ and their non-diabetic cotwins $(0.247(0.147) ; \mathrm{p}<0.05)$ than in the matched controls $(0.187(0.099))$ (table II). There was no significant difference between the values of sodiumlithium countertransport in the diabetic twins and their non-diabetic cotwins $(p=0 \cdot 12)$. Sodium-lithium countertransport activity in the diabetic twins correlated with that of their non-diabetic cotwins $(r=0 \cdot 30$, $\mathrm{p}<0.05$; fig 1 )

Mean (SD) systolic blood pressure $(\mathrm{mm} \mathrm{Hg})$ was significantly higher in the diabetic twins $(127(17))$ than in the non-diabetic cotwins $(122(18) ; \mathrm{p}<0.01)$ and the control group (120 (15); $<<0 \cdot 05$, table II). Systolic blood pressure did not differ significantly between the non-diabetic cotwins and the controls $(p=0 \cdot 58)$. There was no difference between the diabetic and the nondiabetic cotwins $(p=0 \cdot 13)$, the diabetic twins and controls ( $p=0.97$ ), or the controls and the non-diabetic cotwins $(p=0.42)$ with respect to diastolic blood pressure. Systolic blood pressure values in the diabetic and the non-diabetic cotwins correlated positively $(r=$ $0 \cdot 75, \mathrm{p}<0.001$; fig 2 ) with 23 of the 44 data points lying to the left of the line of identity. A similar correlation to that seen with systolic blood pressure was also found between the diastolic blood pressure values of the diabetic twins and the non-diabetic cotwins $(r=0 \cdot 58$, $\mathrm{p}<0.01$ )

TABLE II -Measurements of blood pressure and sodium-lithium countertransport in 44 insulin dependent diabetic twins, their non-diabetic cotwins, and 44 matched control subjects

\begin{tabular}{|c|c|c|c|}
\hline & $\begin{array}{c}\text { Diabetic twins } \\
n=44\end{array}$ & $\begin{array}{c}\text { Non-diabetic } \\
\text { cotwins } \\
n=44\end{array}$ & $\begin{array}{c}\text { Controls } \\
\mathrm{n}=44\end{array}$ \\
\hline \multicolumn{4}{|l|}{ Systolic blood pressure ( $\mathrm{mm} \mathrm{Hg}$ ): } \\
\hline $\operatorname{Mean}(\mathrm{SD})$ & $127(17)$ & $122(18)^{\star \star}$ & $120\langle 15\rangle^{\star}$ \\
\hline $95 \%$ Confidence interval & 122 to 133 & 117 to 127 & $116 t 0125$ \\
\hline \multicolumn{4}{|l|}{ Diastolic blood pressure $(\mathrm{mm} \mathrm{Hg})$ : } \\
\hline Mean (SD) & $80(10)$ & $78(10)$ & $80(10)$ \\
\hline $95 \%$ Confidence interval & 75 to 81 & $77 \mathrm{t} 83$ & 77 to 83 \\
\hline \multicolumn{4}{|l|}{$\mathrm{Na}-\mathrm{Li}$ countertransport $(\mathrm{mmol} \mathrm{Li} / \mathrm{l}$ of red blood cells $/ \mathrm{h})$ : } \\
\hline $95 \%$ Confidence interval & 0.244 to 0.338 & 0.204 to 0.290 & 0.157100 .216 \\
\hline
\end{tabular}

${ }^{\star} \mathrm{p}<0.05$ For comparison with values for the diabetic twins $\star \star p<0.01$ For comparison with values for the diabetic twins. tp<0.05 For comparison with values for the controls.

$t+p<0 \cdot 001$ For comparison with values for the controls.

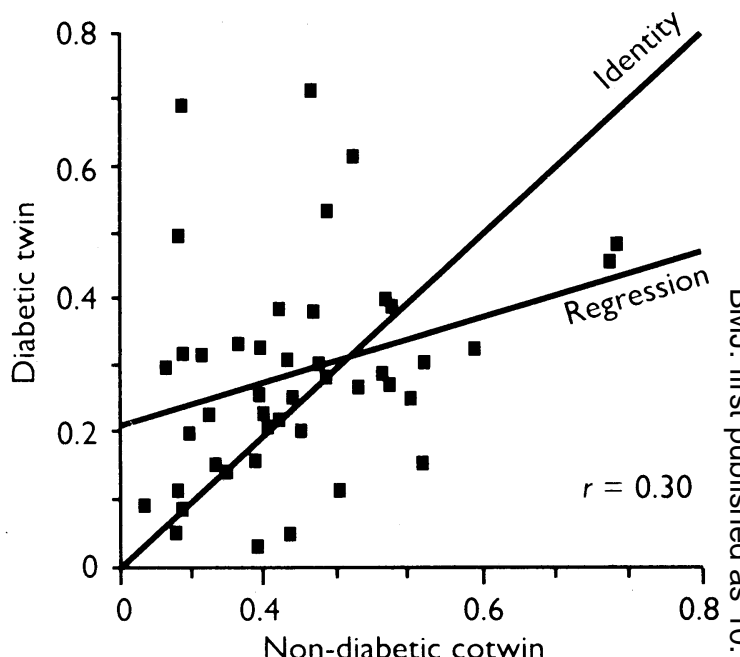

FIG 1-Sodium-lithium countertransport (mmol Li/l of red blood cells/h) in 44 twins with insulin dependent diabetes and their nondiabetic cotwins

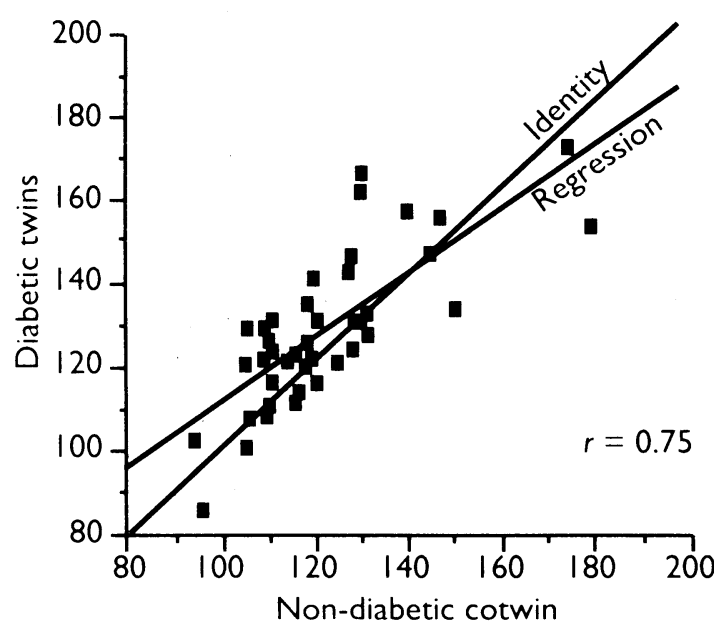

FIG 2 -Sustolic blood pressure ( $\mathrm{mm} \mathrm{Hg}$ ) in 44 twins with insulin $\overrightarrow{\overrightarrow{0}}$ dependent diabetes and their non-diabetic cotwins

Systolic, but not diastolic blood pressure correlated significantly with age in the diabetic twin group $(r=\xi$ $0 \cdot 39, \mathrm{p}<0.05$ (systolic); $r=0 \cdot 11, \mathrm{p}>0 \cdot 1$ (diastolic)), the non-diabetic cotwin group $(r=0.34, \mathrm{p}<0.05 ; r=$ $0 \cdot 20, \mathrm{p}>0 \cdot 1)$, and the controls $(r=0 \cdot 35, \mathrm{p}<0 \cdot 05 ; r=3$ $0 \cdot 09, \mathrm{p}>0 \cdot 1)$. No significant correlations were observed between either systolic or diastolic blood pressure and sodium-lithium countertransport in $\mathrm{O}$ either the diabetic twin group $(r=0 \cdot 06, p>0 \cdot 1 ; r=$ $0.09, \mathrm{p}>0.01)$, the non-diabetic cotwin group $(r=0.08, \stackrel{\sim}{\sim}$ $\mathrm{p}>0.1 ; r=0.04, \mathrm{p}>0.1)$, or the controls $\left(r=0.06\right.$, $\frac{\mathrm{O}}{\mathrm{O}}$ $\mathrm{p}>0.1 ; r=0.03, \mathrm{p}>0.1)$. Duration of diabetes in the diabetic twins showed no correlation with sodium- $N$ lithium countertransport $(r=0 \cdot 23, \mathrm{p}>0 \cdot 1)$, systolic N్ట pressure $(r=0.22, \mathrm{p}>0 \cdot 1)$, or diastolic pressure $\left(r={ }^{\circ}\right.$ $0 \cdot 06, p>0 \cdot 1)$. In addition, sodium-lithium counter-e transport showed no correlation with either random blood glucose or glycated haemoglobin concentrations? in the diabetic twin group $(r=0 \cdot 10, \mathrm{p}>0 \cdot 1$ and $r=0 \cdot 05$, $\mathrm{p}>0 \cdot 1$ respectively), the non-diabetic cotwin group $(r=0 \cdot 18, \mathrm{p}>0 \cdot 1$ and $r=0 \cdot 17, \mathrm{p}>0.1$ respectively), or $\stackrel{\Phi}{\Phi}$ the controls $\left(r=0.23, \mathrm{p}>0.1\right.$ and $r=0.09, \mathrm{p}>0.1 \frac{\mathbb{Q}}{\circ}$ respectively).

\section{Discussion}

Sodium-lithium countertransport activity is influenced predominantly by genetic factors and to a lesser? extent by the environment.' 2 Differences in genetic influence may be an important limitation to the interpretation of results when comparing the countertransport activities in groups of subjects. We hoped 
that by using identical twins discordant for insulin dependent diabetes any possible influence of confounding factors on the sodium-lithium countertransport activity would be minimised.

Essential hypertension and diabetic nephropathy ${ }^{3+}$ have both been linked with abnormal sodium-lithium countertransport activity. We sought to avoid the potential confounding influence of these variables by excluding twin pairs if either of the twins was overtly hypertensive, was taking any antihypertensive drugs, or showed evidence of nephropathy (as reflected by the presence of microalbuminuria).

\section{SODIUM-LITHIUM COUNTERTRANSPORT}

The sodium-lithium countertransport activities of our diabetic twins were similar to, and correlated with, those of their non-diabetic cotwins, although the correlation between the twins was not as strong as that reported elsewhere. ${ }^{1 \times}$ In both the diabetic twins and their non-diabetic cotwins the mean countertransport activity was significantly higher than in the controls Thus overt diabetes itself had no demonstrable effect on the sodium-lithium countertransporter. This conclusion was further supported by the absence of any associations between the sodium-lithium countertransport activity and the duration of diabetes or the degree of the metabolic control as represented by concentrations of glucose and glycated haemoglobin.

Increased erythrocyte sodium-lithium countertransport activity was a feature common to both the diabetic and non-diabetic twins and seems to indicate that the increased countertransport activity observed in insulin dependent diabetes was genetically determined. It suggests that an alteration in the structure of the cell membrane mav be a component of the predisposition to diabetes. As there was some overlap in the levels of sodium-lithium countertransport activity between the diabetic subjects and the controls, as has been noted by other workers, ${ }^{19}$ this inherited trait is unlikely to be dominant. A similar argument may explain the inconsistent results in parents of insulin dependent diabetic patients with nephropathy, in whom the sodium-lithium countertransport activity has been reported to be either increased ${ }^{\mathrm{x}}$ or similar to that of controls." Failure to consider fully the genetic contribution may explain why some of the observed rises in sodium-lithium countertransport in diabetic patients have been incorrectly interpreted as related to disease."

Overall, the mean sodium-lithium countertransport activities of our subjects were consistently lower than those published by some other investigators. ${ }^{619}$ This is likely to reflect methodological differences between laboratories undertaking membrane transport studies. Thus, the choice of sodium free media (for example, magnesium, potassium, or choline chloride) could be critical, ${ }^{20}$ as could be the choice of lithium loading procedure, of which there are several variations..$^{21}$ The problem of the differing methods employed worldwide to quantify countertransport activity has been raised ${ }^{23}$ but has yet to be fully resolved.

Variations in timing of sampling for sodium-lithium countertransport measurements may have introduced the possibility that differences in circulating insulin concentrations may have affected sodium-lithium countertransport activity. Insulin may exert a small acute effect on countertransport activity in vitro, ${ }^{2+}$ but short term in vivo influences of insulin on sodiumlithium countertransport activity have yet to be characterised. We have previously measured sodiumlithium countertransport activity in the fasting and the fed states in healthy volunteers and have observed no consistent differences (unpublished observations). This would suggest that any influence of endogenous insulin is insignificant.

\section{BLOOD PRESSURE}

We found that those twins with insulin dependent diabetes had increased systolic blood pressure compared with their non-diabetic cotwins, yet their absolute blood pressure values lay within the normotensive range. There was also a strong correlation of blood pressure values in the twin pairs. This finding supports the presence of a genetic influence on blood pressure, which has been noted between twin pairs in other investigations. ${ }^{25}$ Systolic blood pressure in the non-diabetic cotwins did not differ from that in the controls. Taken together these observations suggest that, firstly, genetic susceptibility to diabetes in the absence of the diabetic state is not associated with an increased systolic blood pressure and, secondly, the diabetic state itself results in a small increase in systolic blood pressure.

Studies of non-hypertensive diabetic children and young adults have also suggested that insulin dependent diabetes may be associated with an increase in either systolic ${ }^{26}$ or diastolic ${ }^{27}$ blood pressure when compared with non-diabetic subjects. The important issue of possible early nephropathy contributing to raised blood pressure has been taken into account by some workers ${ }^{27}$ but no by others. ${ }^{26}$ The small increase in systolic blood pressure in our diabetic twins could not be ascribed to early renal damage as none of the diabetic twins showed any evidence of microalbuminuria. Apart from renal disease raised blood pressure could arise through increased peripheral vascular resistance or increased plasma viscosity, or both, secondary to poor glycaemic control; improving diabetic control can reduce blood pressure, particularly systolic. ${ }^{28}$ Alternatively hyperinsulinaemia, a feature of patients with insulin dependent diabetes receiving insulin treatment, could activate either the adrenergic nervous system or increase renal tubular reabsorption of sodium..$^{29}$

In conclusion, the raised sodium-lithium countertransport activity observed in the diabetic twins, compared with the controls, emerges as an inherited feature rather than a consequence of the overt diabetic state. The higher systolic blood pressure in the diabetic twins compared with the non-diabetic cotwins indicates that insulin dependent diabetes may have a small influence on systolic blood pressure.

We thank Fiona Irving and Sonia Sandhu for technical help; Simon Lo for carrying out glucose tolerance tests; Robert Goodlad for statistical advice; and Adele Cocoran fo proof reading the manuscript. This study was supported by grants from the Wellcome Trust, Diabetic Twin Research Trust, the British Heart Foundation, and the Joint Trustee of Westminster and Roehampton Hospitals London.

1 Weder AB, Fitzpatrick MA, Torretti BA, Hinderliter AL, Egan BM, Julius S. Red blood cell lithium-sodium countertransport as a genetic marker in essential hypertension. F Hypertens 1986;4(suppl 6):S373-5.

2 Hunt SC, Stephenson SH, Hopkins PN, Hasstedt SJ, Williams RR. A prospective study of sodium-lithium countertransport and hypertension in Utah. Hypertension 1991;17:1-7.

3 Krolewski AS, Canessa M, Warram JH, Laffel LMB, Christlieb AR, Knowler W'C, et al. Predisposition to hypertension and susceptibility to renal disease C, el al. Predisposition to hypertension and susceptibility to renal diseas
in insulin-dependent diabetes mellitus. N Engl f Med 1988;318:140-5.

4 Mangili R, Bending JJ, Scott G. Li LK, Gupta A, Viberti G. Increased sodium-lithium countertransport activity in red cells of patients with sodium-lithium countertransport activity in red cells of patients with insulin-dependent diabetes and nephropathy. $N$ Engl f Med 1988;318:

5 Carr SJ, Mbanya J, Thomas TH, Keavey P, Taylor R, Alberti KGMM, et al. Increase in glomerular filtration rate in patients with insulin-dependen diatetes and elevated erythrocyte sodium-lithium countertransport. $N$ Eng y. Med 1990;322:500-5.

6 Jensen JS, Mathiesen ER, Norgaard K, Hommel E, Borch-Johnsen K, Funder $\mathrm{J}$, et al. Increased blood pressure and erythrocyte sodium/lithium countertransport activity are not inherited in diabetic nephropathy. Diabetologia 1990);33:619-24.

Canessa M, Adragna N, Solomon HS, Connolly TM, Tosteson B, Tosteson DC. Increased sodium-lithium countertransport in red cells of patients with essential hvpertension. N Engl f Med 1980;302:772-6.

8 Walker J1) Tariq T Viberti G Sodium-lithium countertransport activity in red cells of patients with insulin-dependent diabetes and nephropathy and red cells of patients with insulin-den

9 Barnet AH, Eff C, Leslie RDG, Pyke DA. Diabetes in identical twins. A study of 200 pairs. Diabetologia 1981;20:87-93. 
10 World Health Organisation. Arterial hypertension. Report of a WHO exper committee on hypertension. WHO Tech Rep Ser 1979:No 628 .

11 National Diabetes Data Group. Classification and diagnosis of diabetes mellitus and other categories of glucose intolerance. Diabetes 1980;28: 1039.57.

12 Rowe DJF, Dawnay A, Watts GF. Microalbuminuria in diabetes mellitus: review and recommendations for the measurement of albumin in urine. Ann Clin Biochem 1990;27:297-312.

13 Eilers R. Notification of final adoption of an international method and standard solution for hemoglobinometry specifications for preparation of standar solution. Am J Clin Pathol 1967;47:212-4.

14 Smith JB, Price AL, Williams RR, Hentschel WM, Sprowell W, Hunt SC et al. A reproducible sodium-lithium countertransport assay: the outcome of changing key laboratory parameters. Clin Chim Acto 1982:122:327-35

15 Laurenzi M, Trevisan M. Sodium-lithium countertransport and blood pressure: the Gubbio population study. Hypertension 1989;13:408-15.

16 Turner ST, Weidman WH, Michels VV, Reed TJ, Ornon CL, Fuller T, et at. Distribution of sodium-lithium countertransport and blood pressure in Distribution of sodium-lithium countertransport and blow

17 Trevisan M, Ostrow D, Cooper R, Liu K, Sparks S, Stamler J. Methodological assessment of assays for red cell sodium concentration and sodium dependent lithium efflux. Clin Chim Acta 1981;116:319-29.

18 Lewitter FI, Canessa M. Red cell sodium transport studies in adult twin Am $\mathcal{Y}$ Hum Genet 1985; suppl 36:172S.

19 Halkin A, Benjamin A, Doktor HS, Todd SD, Viberti G, Ritter JM. Vascula responsiveness and cation exchange in insulin-dependent diabetes. Clin $S_{C}$ 1991;81:223-32.

20 Smith JB, Weinberger MH, Wade MB. Is the correlation between sodium lithium countertransport and sodium-potasium cotransport an artifact of methodolog? Clin Chim titu 1986:157:317-20.

21 Rutherford PA, Thomas TH, Wilkinson R. Increased erythrocyte sedium lithium countertransport activity in essential hypertension is due to an increased affinity for extracellular sodium. Clin Sci 1990; 79:365-9.

22 Canessa $\mathrm{M}$. Kinetic properties of $\mathrm{Na}^{\prime} / \mathrm{H}^{\prime}$ exchange and $\mathrm{Li}^{\prime} / \mathrm{Na}^{\prime}, \mathrm{Na}{ }^{\prime} / \mathrm{Na}$ and $\mathrm{Na}^{\prime} / \mathrm{Li}^{\prime}$ exchanges of human red cells. Methods Enzymol 1989:173 $176-91$

23 Rutherford PA, Thomas TH, Wilkinson R. Erythrocyte sodium-lithium countertransport: clinically useful, pathophysiologically instructive or jus phenomenology? Clin Sci 1992;82:341-52.

24 Foyle WJ, Drury PL. Reductions in $\mathrm{Li}^{\prime}-\mathrm{Na}^{\prime}$ countertransport by physiological levels of insulin in vivo. I Hypertens 1991:9:713-7.

25 Schicken RM, Eaves LJ, Hewitt JK, Mosteller M, Bodurtha JN, Moskowitz WB, et al. Univariate genetic analysis of blood pressure in children (the medical college of Virginia twin study). A $m \mathcal{F}$ Cardiol 1989;64:1333-7.

26 Kaas Ibsen K, Rotne H. Hougaard P. Blood pressure in children with diabetes mellitus. Actu Paediatr Scand 1983:72:191-6.

27 Tarn AC. Drury PL. Blood pressure in children, adolescents and young adults with type 1 (insulin-dependent) diabetes. Diabetologia 1986:29:275-81.

28 Mathiesen ER, Hilsted J, Feldt-Rasmussen B, Bonde-Petersen F, Chistensen $\mathrm{NJ}$, Parving HH. The effect of metabolic control on hemodynamics in shortterm insulin-dependent diabetic patients. Diabetes 1985;34:1301-5.

29 Ferrari P, Weidmann P. Insulin, insulin sensitivity and hypertension f Hypertens 1990;8:+91-500

\title{
Impact of HIV infection on mortality in young men in a London health authority
}

\author{
John Aldous, Matthew Hickman, Antony Ellam, Brian Gazzard, Sally Hargreaves
}

\begin{abstract}
Objective-To determine the number of deaths attributable to HIV infection among men aged 15-64 in a geographically defined population in the United Kingdom.
\end{abstract}

Design-Retrospective review of death certificates and linkage with local and national HIV and AIDS surveillance data.

Setting-Riverside District Health Authority, London.

Main outcome measures-Numbers of deaths attributed to HIV infection in male residents of Riverside aged 15-64 and $15-44$ over a six month period. Proportion of attributed deaths were (i) identified from death certificates by the Office of Population Censuses and Surveys as being due to HIV infection and (ii) reported as cases of AIDS or HIV related deaths to the Public Health Laboratory Service Communicable Disease Surveillance Centre.

Results - 34 of 213 (16\%) deaths in men aged 15-64 and 27 of $69(39 \%)$ deaths in men aged 15-44 were attributed to HIV infection. Six of $33(18 \%)$ attributed deaths were identified by the Office of Population Censuses and Surveys and 32/34 (94\%) were reported to the Communicable Disease Surveillance Centre.

Conclusions - HIV infection was the leading cause of death in male residents of Riverside aged 15-44 and the third commonest cause of death in those aged 15-64. Most individuals dying of known HIV infection were reported to the Communicable Disease Surveillance Centre but identification of the true cause of death from the process of death certification was poor. Measures to improve the certification of HIV and AIDS or the use of AIDS surveillance information correctly to code the cause of death needs to be considered to ensure that the true impact of HIV infection is reflected in routine mortality statistics.

Dr J Aldous, Department of Public Health, District

Headquarters, Ealing

Hospital, St Bernard's

Wing, Southall, Middlesex UB1 3EU.

BMF 1992;305:219-21 and in some cities in the United States' and Africa ${ }^{2}$ it is the leading cause of death in young adult men.

Information on mortality from HIV infection in $\vec{\oplus}$ England and Wales is obtained from two main sources: $N$ the Office of Population Censuses and Surveys, which compiles mortality statistics derived from information on death certificates, and the Public Health Laboratory Service Communicable Disease Surveillance Centre, which runs the national AIDS surveillance system. Concerns have been expressed that information from these two sources may considerably underestimate the mortality from HIV infection. There are two main reasons. Firstly, HIV infection or AIDS is frequently not recorded on death certificates owing to concerns over confidentiality arising from the public nature of these documents. ${ }^{3}$ Secondly, although AIDS surveillance can provide useful information on mortality in people diagnosed as AIDS cases (subject to a small degree of underreporting of AIDS cases and some delays in identifying deaths in reported cases $)^{45}$ the number of infected people who die before developing 옥 or being diagnosed as having an AIDS indicator disease $N$ is not known.

This study was undertaken to determine the number of deaths attributable to HIV infection in males aged between 15 and 64 resident in Riverside Health Authority, London.

\section{Subjects and methods}

Riverside Health Authority covers an area of inner London with a high prevalence of HIV infection. Specialist care for people with HIV infection is provided at several centres, which together have reported around $25 \%$ of the AIDS cases in England and Wales.

Copies of the death certificates of residents of the health authority and of homeless people dying within 8 the district are routinely sent to the public health department and entered on to a computerised mortality register. A previous study had established a local database of people known to be infected with HIV (HIV database). ${ }^{*}$ Surnames on this database were anonymised by soundex code. ${ }^{4}$

The mortality register was used to identify all deaths 